\title{
Experimental Study on the Flexural Behavior of Reinforced Polystyrene Blocks in Concrete Beams
}

\author{
Yong Tat Lim*, Jen Hua Ling, Ji Wei Lau, Yik Yee Min Alicia \\ School of Engineering and Technology, University College of Technology Sarawak, Sibu, Sarawak, MALAYSIA \\ No. 1, Jalan Universiti, 96000 Sibu, Sarawak, MALAYSIA \\ *Corresponding authors: limyongtat@ucts.edu.my
}

SUBMITTED 18 December 2020 REVISED 12 February 2021 ACCEPTED 15 March 2021

\begin{abstract}
A new type of lightweight beam system was recently proposed by embedding polystyrene in beams to improve structural efficiency. This removes the non-performing concrete in the neutral axis and tension region to provide a comparable strength as a solid beam. There are, however, limited studies conducted to investigate the structural behavior of such beams. Therefore, this research presents an experimental investigation to assess the effect of polystyrene shapes in the beams. This involved testing a solid beam and five lightweight beams under flexural load using a four-point load test. The inclusion of polystyrene was estimated to have reduced the self-weight of beams by $8.6 \%$ to $11.8 \%$ when compared with the solid beam. The results also showed the ellipse polystyrene with a width of $70 \mathrm{~mm}$ and height of $50 \mathrm{~mm}$ produced the highest effective strength to weight ratio $(\mathrm{sw})$ of 1.12 and performed $12 \%$ better than the solid beam. Moreover, the lightweight beams have more weight reduced than the strength, and those with ellipse polystyrene were found to have performed better than circular ones based on first crack load, ultimate load, and effective strength to weight ratio ( $\mathrm{sw}$ ). The beams with ellipse polystyrene allowed better stress distribution and this gave them a higher strength than sphere shape. For industry application, the polystyrene content is recommended to be greater than $10 \%$ while the effective strength to weight ratio ( $\mathrm{sw}$ ) of the beam is greater than 1 . The successful reduction of the weight without affecting the structural performance has the ability to help in reducing construction costs.
\end{abstract}

KEYWORDS Reinforced concrete; Lightweight system; Polystyrene blocks; Shape; Beam.

(c) The Author(s) 2021. This article is distributed under a Creative Commons Attribution-ShareAlike 4.0 International license.

\section{INTRODUCTION}

The main design limitation in a reinforced concrete structure is the self-weight which is governed by the span between columns. This is observed in the need for a larger depth by a longer span to sustain loads. Therefore, the reduction of the weight of beams is considered an effective way to lighten the reinforced concrete structures. This, in turn, allows for reduced sizes of columns and foundations, thereby, decreasing the total cost of the building.

There is, however, currently no efficient lightweight beam design with a decent strengthto-volume ratio. For some reason, the beams lose more strength than weight in percentage (Ahmad and Hadi, 2014; Jesudhason and Hemalatha, 2014). This, therefore, leads to the question of whether the system has been fully established.
Several studies have been conducted to assess the performance of lightweight beams and the flexural strength was observed to have been influenced by the shapes of the lightweight materials as shown in Figure 1. The square shape offered lower flexural capacity than the sphere shape by $4.35 \%$ (Manikandan, Dharmar, and Robertravi, 2015).

This phenomenon is probably associated with the sharp edge of lightweight materials which causes high stress concentrates at the tip. These detrimental effects, however, reduce when the corner radius increase and the stress is equally distributed (Chung et al., 2010). Hai et al. (2013) also showed that the ellipse shape material in a structure offered $4.7 \%$ to $5.4 \%$ higher strength than the sphere. This research was, however, at 


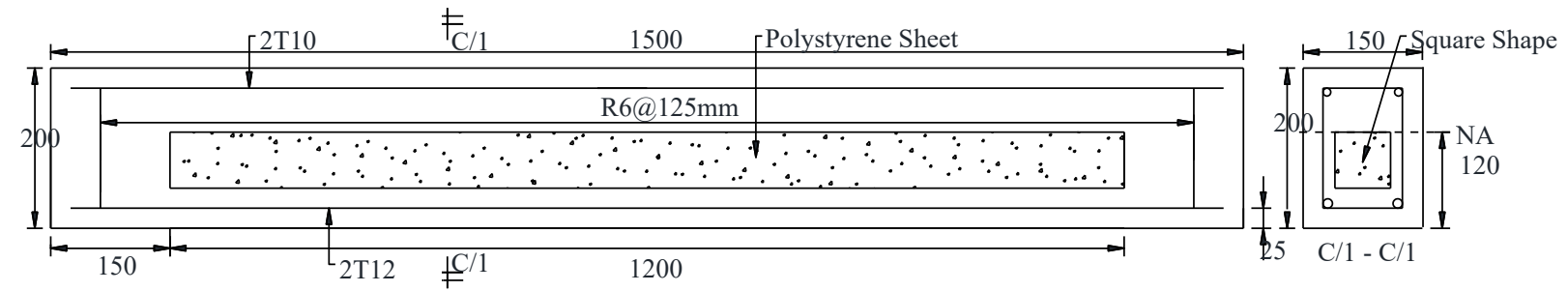

(a) Beam with Square Polystyrene (Manikandan, Dharmar, and Robertravi, 2015)

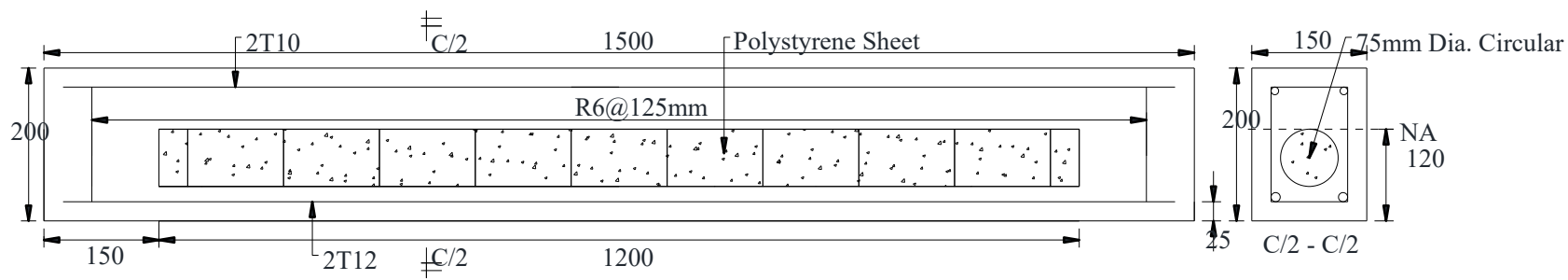

(b) Beam with Circular Polystyrene (Manikandan, Dharmar, and Robertravi, 2015)

Figure 1. Typical Detailing of the Lightweight Beam

the exploratory stage and the principle was not fully established. Moreover, only one type of shape was used within one structural element and this means the effects of different shapes in an element are presently not known.

This research, therefore, focuses on the responses of the lightweight beam by incorporating polystyrene of different shapes. This was achieved through experiment tests conducted under incremental flexural load. The aim was to determine the shape with the highest effective strength to weight ratio $(\mathrm{sw})$ for the lightweight beam

\section{EXPERIMENTAL PROGRAM}

\subsection{Specimen Details}

A solid beam and five lightweight beams were tested under a four-point load test as shown in Table 1. The beams were prepared to be $175 \mathrm{~mm}$ wide, $300 \mathrm{~mm}$ height, and $1600 \mathrm{~mm}$ long while the effective length, $l_{\text {eff }}$, between the supports was $1500 \mathrm{~mm}$.
Cylindrical polystyrene blocks with circular and ellipse cross-sections were tied to the steel reinforcements at the neutral axis and tension regions using galvanized wires. The spacing between the blocks was $25 \mathrm{~mm}$ and three units were (a) vertically arranged side by side, (b) 6 group longitudinally, and (c) 5 spacing ribs between each group as shown in Figures 2, 3, and 4.

All the specimens were reinforced with two bottom reinforcements (2T12), two top reinforcements (2T10), and eleven shear links (11R6 - 150). The nominal yield strength of the reinforcement was $500 \mathrm{MPa}$ while the mild steel bar was $250 \mathrm{MPa}$. Meanwhile, the concrete cover of the beam was $25 \mathrm{~mm}$.

The specimens were cast in plywood molds using ready-mixed concrete grade 25 with a $60 \mathrm{~mm}$ to $180 \mathrm{~mm}$ design slump. The specimens were cured at the atmospheric temperature of $30 \pm 5^{\circ} \mathrm{C}$ for 28 days before they were tested as shown in Figure 2 . 


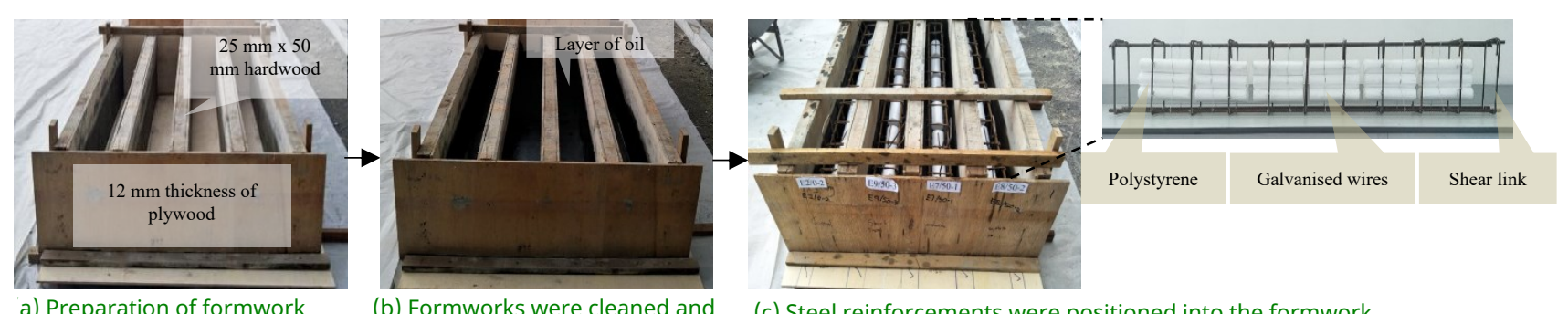

a) Preparation of formwork

(b) Formworks were cleaned and coated with a layer of oil

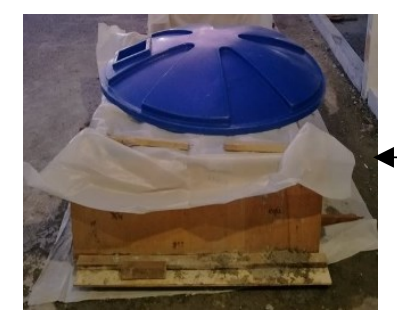

(g) Beam was cured 28 days by covering with wet plaster sheet

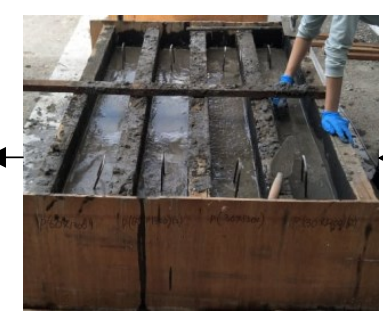

(f) Surface of the beam was smoothened

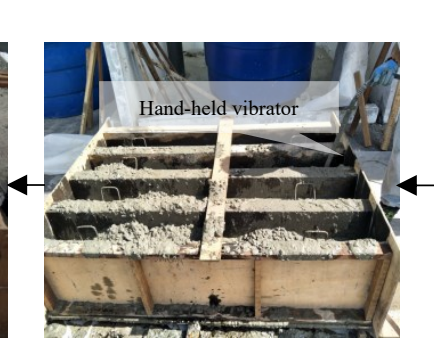

(e) Concrete was vibrated and compacted using a hand-held vibrator

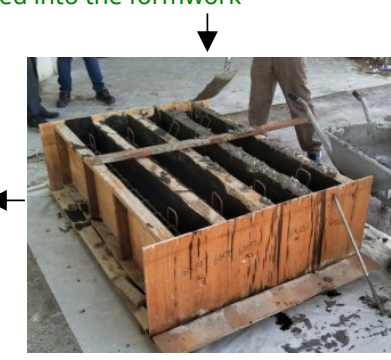

(d) Concrete was poured into the formwork

Figure 2. Preparation of the Beam Specimen

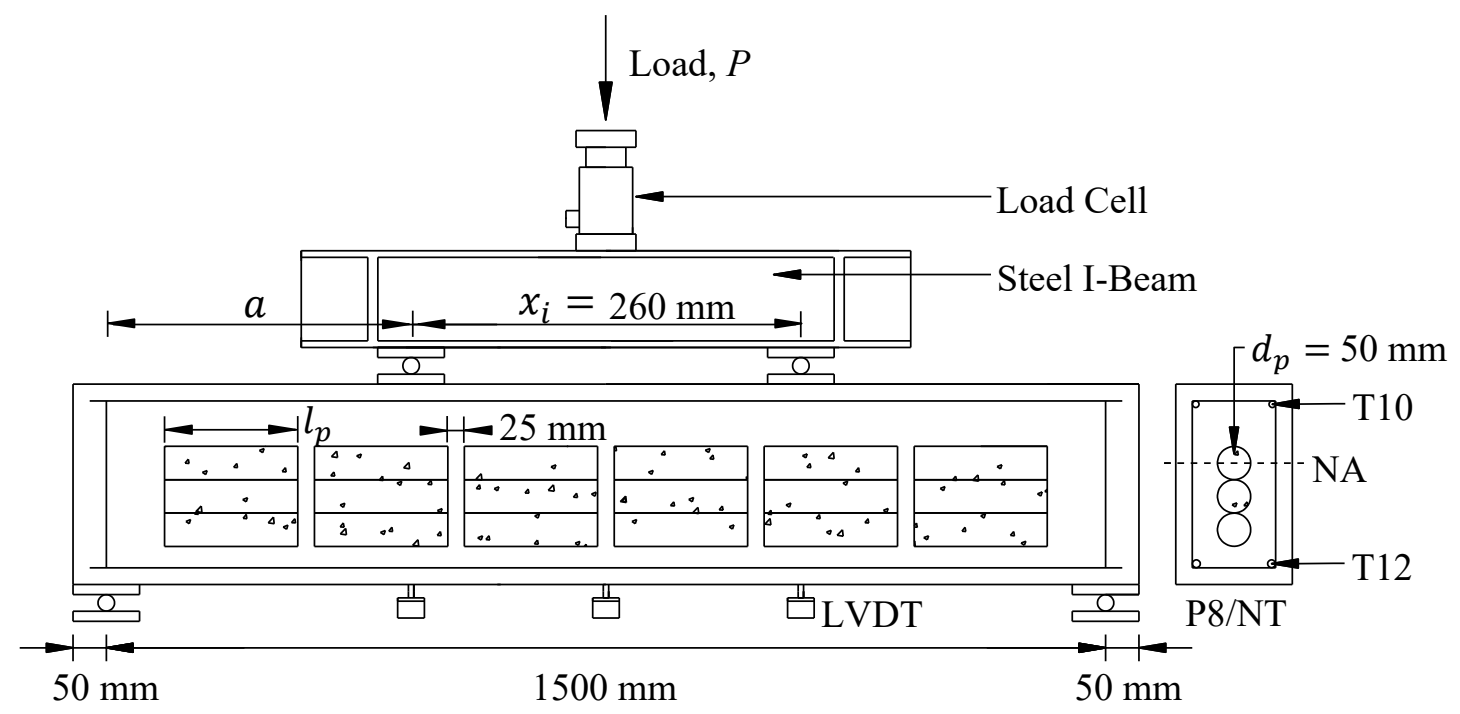

Figure 3. Test Setup

Table 1. Specimens Details

\begin{tabular}{|c|c|c|c|c|c|}
\hline \multirow{2}{*}{ Specimens } & \multicolumn{4}{|c|}{ Geometrical Properties } & \multirow{2}{*}{$\begin{array}{l}\text { Percentage of } \\
\text { Replacement, } V(\%)\end{array}$} \\
\hline & Shape S1 $^{* 1}$ & Diameter (mm) & Width (mm) & Height (mm) & \\
\hline P1 & - & - & - & - & - \\
\hline $\mathrm{F} 1 / 50$ & $\mathrm{~S}$ & 50 & - & - & 8.6 \\
\hline $\mathrm{F} 2 / 60$ & $\mathrm{E}_{1}$ & - & 60 & 50 & 10.1 \\
\hline F3/70 & $\mathrm{E}_{2}$ & - & 70 & 50 & 11.8 \\
\hline $\mathrm{F} 4 / 50-60-70$ & $S, E_{1}, E_{2}$ & 50 & 60,70 & 50 & 10.1 \\
\hline $\mathrm{F} 5 / 70-60-50$ & $E_{2}, E_{1}, S$ & 50 & 70,60 & 50 & 10.1 \\
\hline
\end{tabular}

Notes: ${ }^{* 1} \mathrm{~S}=$ Circular (diameter of $50 \mathrm{~mm}$ ), $\mathrm{E}_{1}=$ Ellipse (width of $60 \mathrm{~mm}$, height of $50 \mathrm{~mm}$ ), $\mathrm{E}_{2}=$ Ellipse (width of $70 \mathrm{~mm}$, height of $50 \mathrm{~mm}$ ) 


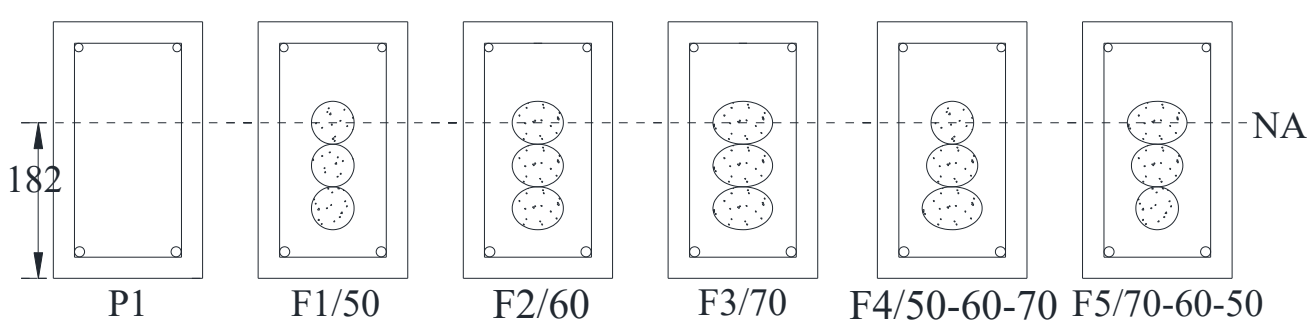

Figure 4. Geometrical Properties of Polystyrene by Specimens

\subsection{Test Setup}

The specimens were tested under flexural load as shown in Figure 5 and the distance between the applied loads, $x_{i}$, was $260 \mathrm{~mm}$ which is equivalent to effective depth $(d)$. The $a / d$ ratio was 2.4 and this caused flexural failure as presented in Table 2 . The increase in $a / d$ ratio led to the reduction of the shear capacities, thereby, changing the failure mode from shear to flexural.

A load cell was placed between the hydraulic cylinder and the distribution beam to measure the applied load. Moreover, three Linear Variable Differential Transducers (LVDT) were positioned under the specimen to monitor the deflection at the mid-span and below the applied loads. All the measuring instruments were connected to a data logger for data acquisition and the summary of their specifications is presented in Table 3.

\subsection{Test Procedure}

The beam was preloaded not to be greater than $10 \%$ of the predicted beam capacity to consolidate the test setup. The applied load was released after 5 minutes to observe the reading recovered to zero in order to check the validity of the instruments. The process was repeated twice. Moreover, the specimen was incrementally loaded at an interval of $5 \mathrm{kN}$ or $0.1 \mathrm{~mm}$ mid-span displacement, whichever was first achieved. The load was maintained for at least 1 minute before the readings were recorded. The test was stopped after load drops continuously five times signifying the failure of the beam.

\section{TEST RESULTS}

\subsection{Material Properties}

Tables 4 and 5 summarize the specifications of the materials used in fabricating the beam. The properties were consistent and attained the desired strengths of the materials and this means they are acceptable.

Table 2. Failure mode due to the $a / d$ ratio

\begin{tabular}{lllcl}
\hline Author & $\begin{array}{l}a^{* 1} \\
(\mathrm{~mm})\end{array}$ & $\begin{array}{l}d^{* 2} \\
(\mathrm{~mm})\end{array}$ & $\begin{array}{c}\frac{a}{d} \\
\text { Ling et. al., (2019) }\end{array}$ & $\begin{array}{l}\text { Failure } \\
\text { Mode }\end{array}$ \\
\hline $\begin{array}{l}600 \\
\text { Mathew and }\end{array}$ & 261 & 1.9 & $\begin{array}{l}\text { Shear } \\
\text { Flexural }\end{array}$ \\
\hline Varghese (2016) & 567 & 261 & 2.2 & Flexural \\
\hline Thaar (2015) & 450 & 266 & 1.7 & Shear \\
\hline
\end{tabular}

Notes: ${ }^{* 1} a=$ Distance between point load and support, $\mathrm{mm}$

${ }^{* 2} d=$ Effective depth, $\mathrm{mm}$

Table 3. Description of the Experimental Equipment

\begin{tabular}{llll}
\hline Equipment & Description & Unit & Accuracy \\
\hline Hydraulic & Push $+933 \mathrm{kN}$ & - & - \\
Jack & Pull $-435 \mathrm{kN}$ & & \\
Hydraulic & Control the & - & - \\
Pump & hydraulic jack & & \\
Load Cell & Capacity $300 \mathrm{kN}$ & $\mathrm{kN}$ & 0.01 \\
LVDT & Capacity $100 \mathrm{~mm}$ & $\mathrm{~mm}$ & 0.01 \\
Data & 30 channels static & - & - \\
Logger & data acquisition & & \\
\hline
\end{tabular}

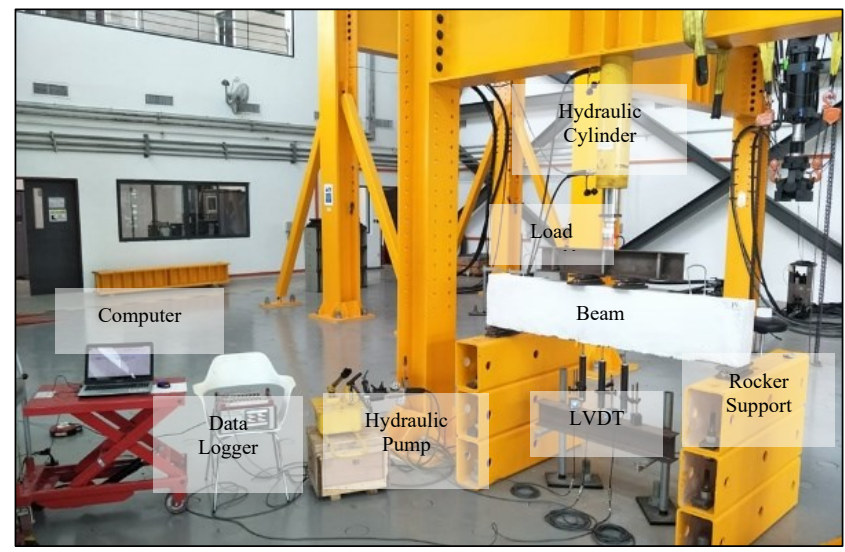

Figure 5. Setup of Laboratory Test 
Table 4. Test Results of Concrete

\begin{tabular}{|c|c|c|c|c|c|c|}
\hline \multirow{2}{*}{ Specimens } & \multicolumn{2}{|c|}{ Concrete Cube $\left(\mathrm{N} / \mathrm{mm}^{2}\right)^{* 1}$} & \multirow{2}{*}{$\begin{array}{l}\text { Average Compressive } \\
\text { Strength }\left(\mathrm{N} / \mathrm{mm}^{2}\right)^{* 2}\end{array}$} & \multicolumn{2}{|c|}{ Density $\left(\mathrm{kg} / \mathrm{m}^{3}\right)^{* 1}$} & \multirow{2}{*}{$\begin{array}{l}\text { Average Density } \\
\left(\mathrm{kg} / \mathrm{m}^{3}\right)^{* 2}\end{array}$} \\
\hline & S1 & S2 & & S1 & S2 & \\
\hline P1 & 25.0 & 25.5 & 25.3 & 2304.0 & 2325.3 & 2314.7 \\
\hline $\mathrm{F} 1 / 50$ & 25.0 & 25.5 & 25.3 & 2304.0 & 2325.3 & 2314.7 \\
\hline $\mathrm{F} 2 / 60$ & 27.0 & 25.2 & 26.1 & 2368.6 & 2408.6 & 2388.6 \\
\hline F3/70 & 25.2 & 24.7 & 25.0 & 2323.3 & 2384.0 & 2353.7 \\
\hline$F 4 / 50-60-70$ & 25.0 & 25.5 & 25.3 & 2304.0 & 2325.3 & 2314.7 \\
\hline F5/70-60-50 & 25.2 & 24.7 & 25.0 & 2323.3 & 2384.0 & 2353.7 \\
\hline
\end{tabular}

Notes: ${ }^{* 1}$ S1 = Specimen 1, S2 = Specimen 2 (tested accordance to BS EN 12390-3:2009)

${ }^{* 2}$ The concrete achieved the desired strength of $25 \mathrm{~N} / \mathrm{mm}^{2}$

Table 5. Test Results of Reinforcement

\begin{tabular}{llllll}
\hline \multirow{2}{*}{ Type of Steel Bar } & \multirow{2}{*}{ Diameter $(\mathrm{mm})$} & \multicolumn{3}{c}{ Yield Stress $(\mathrm{MPa})^{* 1}$} & \multirow{2}{*}{ Average Yield Stress $(\mathrm{MPa}) * 2$} \\
\cline { 3 - 5 } & & $\mathrm{T} 1$ & $\mathrm{~T} 2$ & $\mathrm{~T} 3$ & \\
\hline \multirow{2}{*}{ High yield steel bar } & 10 & 590 & 640 & 635 & 621.7 \\
& 12 & 531 & 670 & 660 & 620.3 \\
\hline Mild steel bar & 6 & 290 & 279 & 285 & 284.7
\end{tabular}

Notes: ${ }^{* 1} \mathrm{~T} 1$ = Specimen 1, T2 = Specimen 2, T3 = Specimen 3 (tested accordance to BS EN ISO 6892-1:2016)

${ }^{* 2}$ The high yield steel and mild steel achieved their desired strength of $500 \mathrm{MPa}$ and $250 \mathrm{MPa}$ respectively.

\subsection{Test Results of Specimens}

The load-deflection response ( $P-\delta$ curve) of the specimens is presented in Figures 6 and 7 . Meanwhile, Table 6 shows the results of the first crack load $\left(P_{i}\right)$, yield load $\left(P_{y}\right)$, ultimate load $\left(P_{u}\right)$, deflection $(\delta)$, and ductility $(\Delta)$.

The load-deflection response was generally divided into three specific regions including the pre-crack stage which is an elastic region before the yielding of the beam, multiple cracking stages which is a transition region with gradual yielding of the beam, and the post-cracking stage which is a region of full plastic deformation (Shaaban et al., 2018) as indicated in Figure 6.

Initially, all the beams were able to sustain a high degree of stiffness as represented by the gradient of the load-deflection curve. This stiffness slightly decreased after the first crack occurred at approximately $1 / 3$ of the beam capacity. This happened when the tensile stress generated in concrete exceeded its modulus of rupture. Moreover, the crack was initiated from the beam's soffit at the mid-span region and gradually propagated upward.

The specimen yielded between $100.98 \mathrm{kN}$ to $108.82 \mathrm{kN}$ when elasticity was lost and experienced plastic deformation. The stiffness decreased and deflection increased drastically at this stage with respect to small increments of load. As the load increased, the cracks widened excessively until the specimen reached its ultimate state and loses its ability to resist the load.

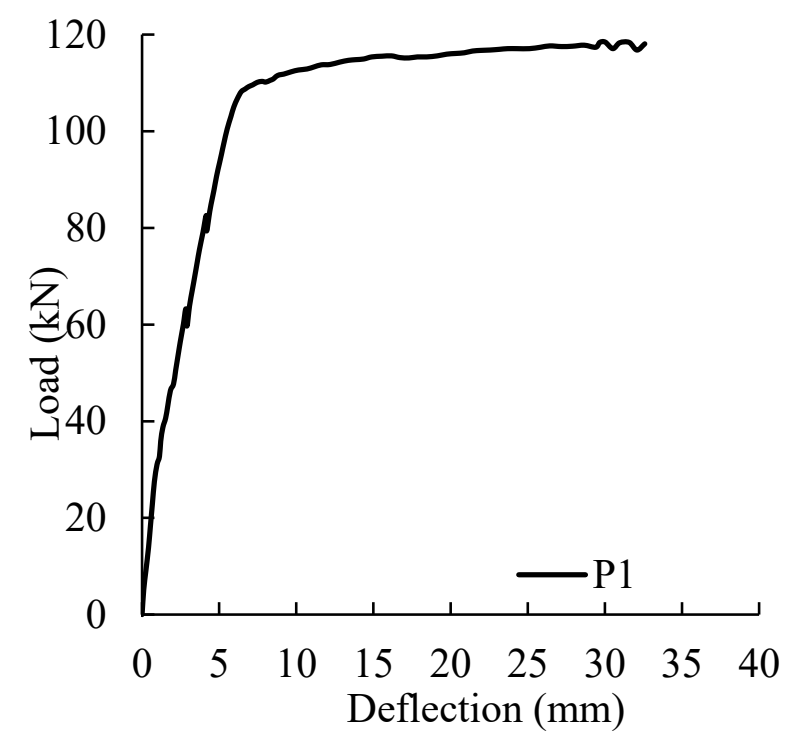

Figure 6. Load-Deflection Curve for Solid Beam Note: The deflection of the curves represents the mid-span deflection of the beam. 


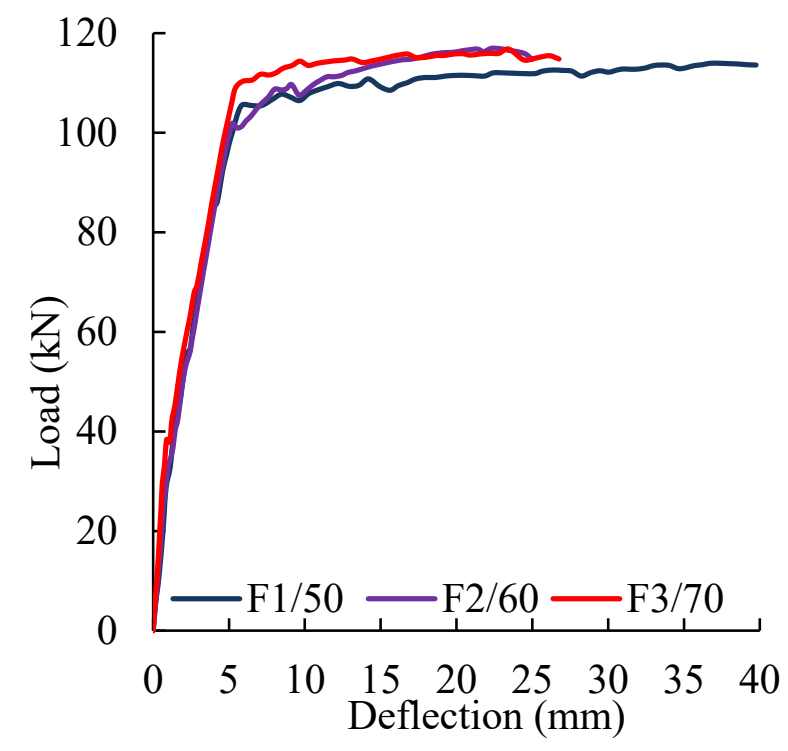

(a) Specimens F1/50, F2/60, and F3/70

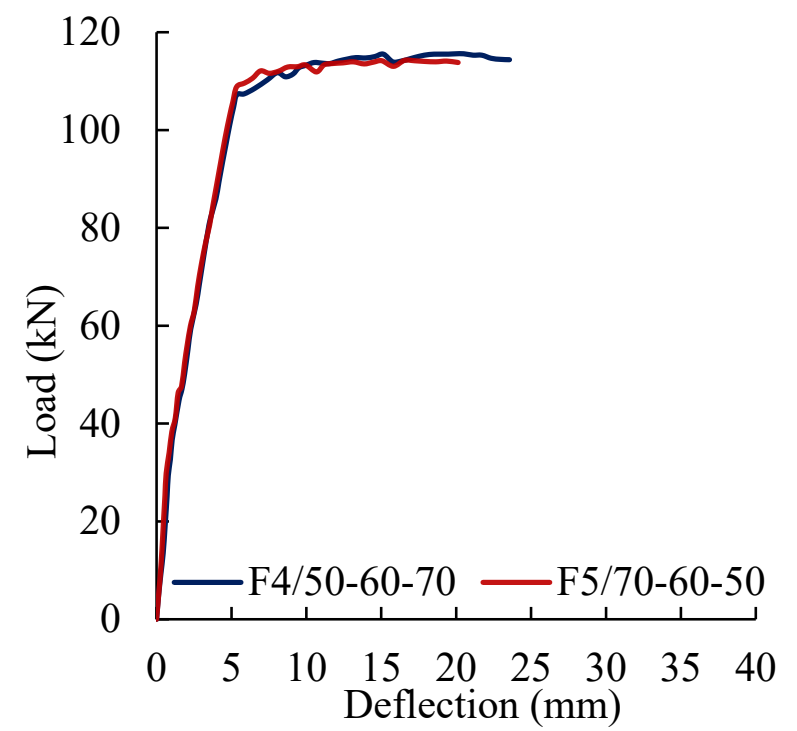

(b) Specimens F4/70-60-50 and F5/50-60-70

Figure 7. Load-Deflection Curve for Lightweight Beams Note: The deflection of the curves represents the mid-span deflection of the beam.

The experimental results are tabulated in Table 6 and the lightweight beams were found to have generally provided a lower ultimate capacity than the solid beam. The removal of the concrete affected the distribution of stress within the beam. Moreover, the use of polystyrene also has the ability to reduce the bonding strength between the concrete and the reinforcement bars, thereby, leading to a lower ultimate load for the beam.
The strength reduction ability of the lightweight beams was, however, $5 \%$ lower when compared to the solid beam. This was due to the fact that the capacity of the beam was governed by concrete in the compression region. It is also possible to neglect the tension region of the concrete in terms of structural capacity (Mohamad and Ramli, 2012).

In terms of shape, the beams with ellipse polystyrene performed better than those with a circular shape. The comparison of specimens F3/70 and F1/50 showed the yield strength and ultimate load increased by $4.5 \%$ and $2.5 \%$ respectively for the additional reduction of the beam's weight. The ellipse allowed stress to be equally distributed along a longer perimeter length of the polystyrene than the circular shape as indicated in Figure 8. This means there was less stress concentrated around the lightweight material and this makes the beam to be less vulnerable to cracking failure.

Specimen F2/60 was observed to have the highest ultimate strength of $116.95 \mathrm{kN}$ among the beams with ellipse polystyrene followed by specimen F3/70. The capacity of the lightweight beam was governed by the second moment of inertia. Specimen F2/60 had a value than F3/70 and gives it a higher load capacity to withstand bending resistance.

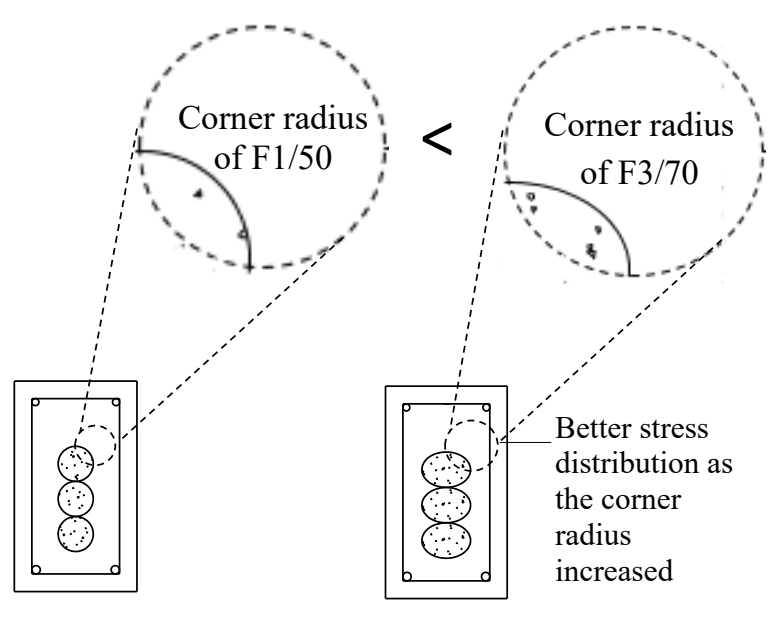
(a) $F 1 / 50$
(b) F3/70

Figure 8. Stress Distribution of Lightweight Beam 
Table 6. Experimental Results of the Specimens

\begin{tabular}{|c|c|c|c|c|c|c|c|}
\hline \multirow[b]{2}{*}{ Specimens } & \multicolumn{2}{|c|}{ Elastic State } & \multicolumn{2}{|c|}{ Yield State } & \multicolumn{2}{|c|}{ Ultimate State } & \multirow[b]{2}{*}{$\begin{array}{l}\text { Ductility, } \\
\Delta=\frac{\delta u}{\delta y}\end{array}$} \\
\hline & $\begin{array}{l}\text { First Crack } \\
\text { Load, } P_{i} \\
(\mathrm{kN})\end{array}$ & $\begin{array}{l}\text { Stiffness, } \\
E_{o .75 u} \\
(\mathrm{kN} / \mathrm{mm})\end{array}$ & $\begin{array}{l}\text { Yield } \\
\text { Strength, } \\
P_{y}(\mathrm{kN}) \\
\end{array}$ & $\begin{array}{l}\text { Yield } \\
\text { Deflection } \\
\delta_{y}(\mathrm{~mm}) \\
\end{array}$ & $\begin{array}{l}\text { Ultimat } \\
\text { e Load, } \\
P_{u}(\mathrm{kN})\end{array}$ & $\begin{array}{l}\text { Ultimate } \\
\text { Deflection, } \\
\delta_{u}(\mathrm{~mm})\end{array}$ & \\
\hline $\mathrm{P} 1$ & 31.02 & 18.84 & 108.75 & 6.69 & 118.45 & 30.02 & 4.49 \\
\hline $\mathrm{F} 1 / 50$ & 32.73 & 29.22 & 105.56 & 5.86 & 113.95 & 36.73 & 6.27 \\
\hline $\mathrm{F} 2 / 60$ & 33.02 & 33.69 & 100.98 & 5.52 & 116.95 & 22.29 & 4.04 \\
\hline F3/70 & 37.87 & 34.43 & 110.32 & 5.89 & 116.81 & 23.45 & 3.98 \\
\hline $\mathrm{F} 4 / 50-60-70$ & 36.65 & 35.24 & 107.39 & 5.84 & 115.59 & 19.96 & 3.42 \\
\hline $\mathrm{F} 5 / 70-60-50$ & 38.37 & 37.62 & 108.82 & 5.34 & 114.24 & 16.54 & 3.10 \\
\hline
\end{tabular}

Specimen F5/70-60-50 seems to be more favorable than F4/50-60-70 in terms of early performance as implied by a higher first crack load, yield strength, and stiffness. This was probably due to the orientation of polystyrene with a smaller width placed at the bottom to reduce the concrete to be replaced near the soffit. This beam had a larger concrete volume surrounded by the reinforcement to resist the tensile stress in concrete, thereby, causing the delay of first crack occurrence as shown in Figure 9.

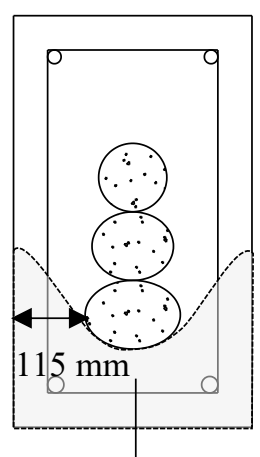

Lower volume of concrete to withstand the tensile stress of concrete

(a) F4/50-60-70

Figure 9. Tensile Resistance of the Lightweight Beam

The orientation of polystyrene, however, offered a limited contribution to the performance of the beam at the later stage. The concrete was unable to contribute to the bending resistance of the beam after it cracked. This was particularly observed at the ultimate state where the concrete was severely cracked and its tensile resistance became ineffective (Zainorizuan et al., 2016). Therefore, it was unable to increase the ultimate load of the lightweight beam.

Meanwhile, most of the lightweight beams had lower ultimate deflection and ductility than the solid beam. This was due to the inability of the deflection to reach the maximum as the specimen failed abruptly, thereby, reducing the deflection at failure.

The comparison of the lightweight beams' ductility showed specimen F1/50 had the highest value. This was probably associated with its larger concrete volume but further study is required to verify this result.

\subsection{Failure Mode}

The failure mode of the beams was visually observed from the crack patterns as indicated in Figure 10 based on the characteristics outlined in Table 7.

Most of the cracks were found to be flexural followed by diagonal tension as shown in Table 8 . There were approximately (a) 4 to 5 flexural cracks, (b) 2 to 4 diagonal tension cracks, and (c) no shear compression crack.

Flexural crack was observed to be more critical than the others in terms of width. This signifies that (a) the specimen failed under flexural mode and (b) the shapes of polystyrene did not influence the failure mode of the beams. 
Table 7. Criteria of Failure Mode

\begin{tabular}{lllllll}
\hline \multirow{2}{*}{ Failure Mode } & \multicolumn{7}{c}{ Criteria } \\
\cline { 2 - 7 } & $\begin{array}{l}\text { At mid-span } \\
\text { propagate } \\
\text { upwards*1 }\end{array}$ & $\begin{array}{l}\text { At 1.5d to 2.0d } \\
\text { distance from } \\
\text { the support }\end{array}$ & $\begin{array}{l}\text { At the support crush } \\
\text { toward compression } \\
\text { zone }^{* 3}\end{array}$ & $W_{f}>W_{s}^{* * 4}$ & $W_{f} \approx W_{s}$ & $W_{f}<W_{s}$ \\
\hline Flexural & $\sqrt{\mathrm{X}}$ & $\mathrm{X}$ & $\sqrt{\mathrm{X}}$ & $\mathrm{X}$ & $\mathrm{X}$ \\
Diagonal Tension & $\mathrm{X}$ & $\sqrt{\mathrm{X}}$ & $\mathrm{X}$ & $\mathrm{X}$ & $\sqrt{\mathrm{X}}$ & $\mathrm{X}$ \\
Shear Compression & $\mathrm{X}$ & $\mathrm{X}$ & $\sqrt{ }$ & - & $\mathrm{X}$ & $\sqrt{ }$ \\
Reference & (Nor and Roslli, 2014) & & & - \\
\hline
\end{tabular}

Notes: $* 1$ at angle of $0^{\circ}$ to $30^{\circ}$

*2at angle of $30^{\circ}$ to $60^{\circ}$ (Kum, 2011)

*3at angle of $45^{\circ}$ (Moayyad and Naiem, 2013)

${ }^{* 4} W_{f}=$ Width of the flexural crack $(\mathrm{mm}), W_{s}=$ Width of the shear crack $(\mathrm{mm})$

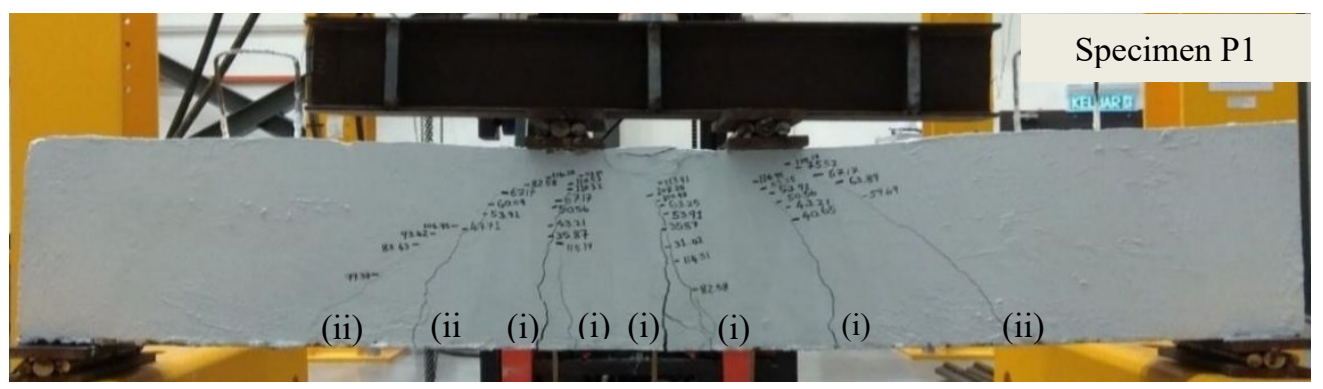

(a) Specimen P1

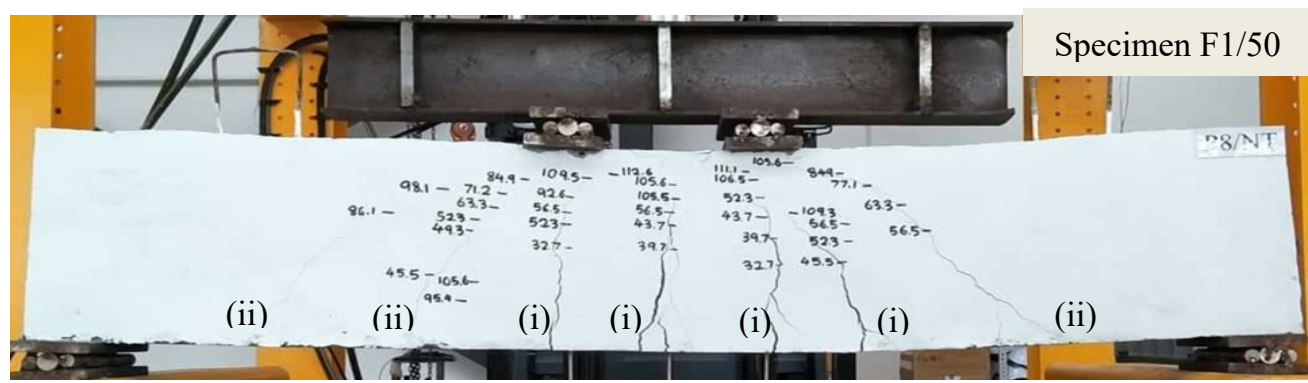

(b) Specimen F1/50

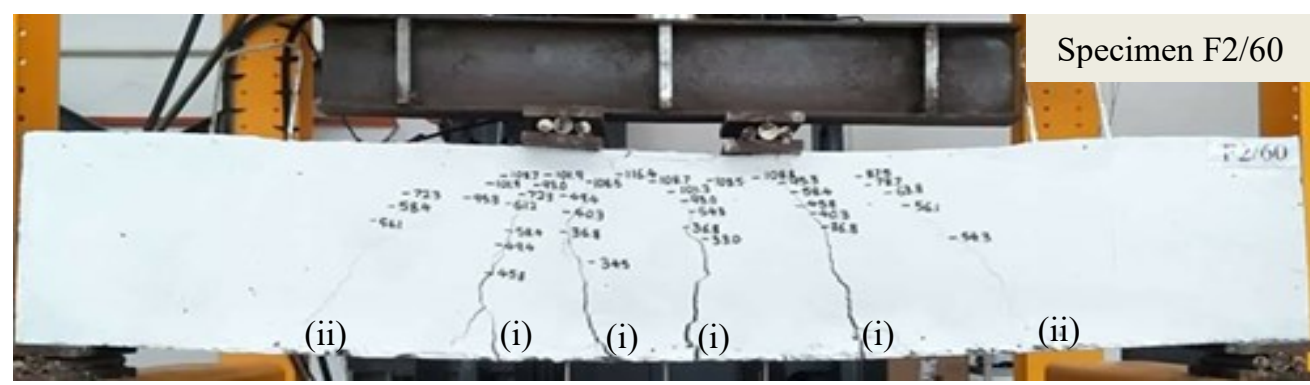

(c) Specimen F2/60

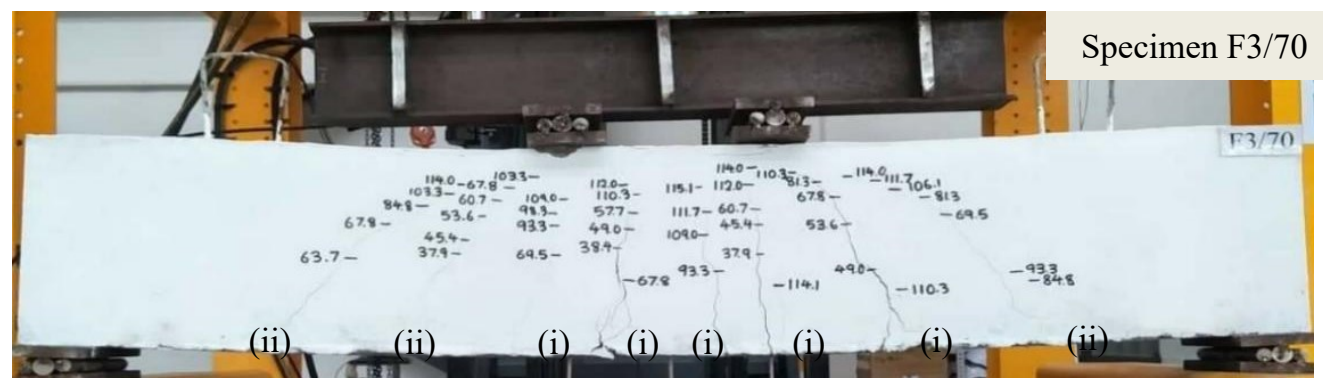

(d) Specimen F3/70 


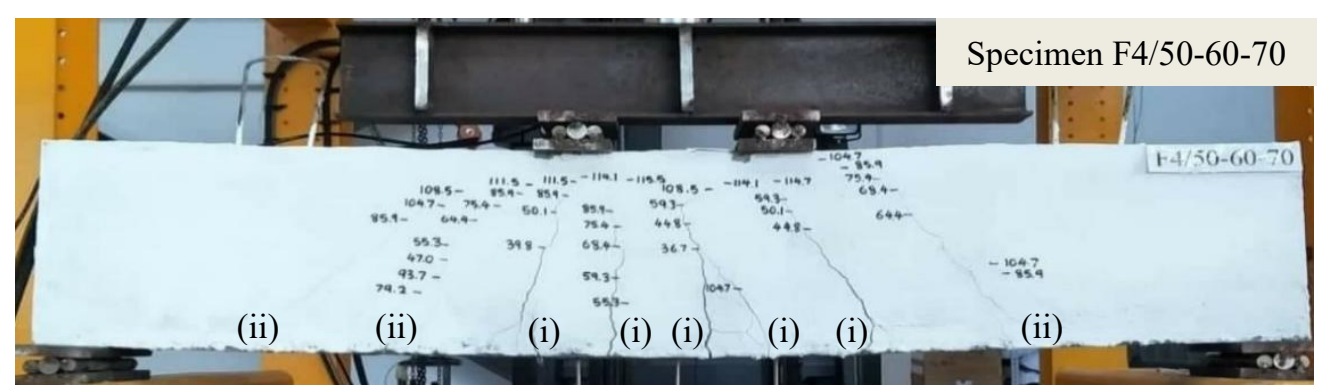

(e) Specimen F4/50-60-70

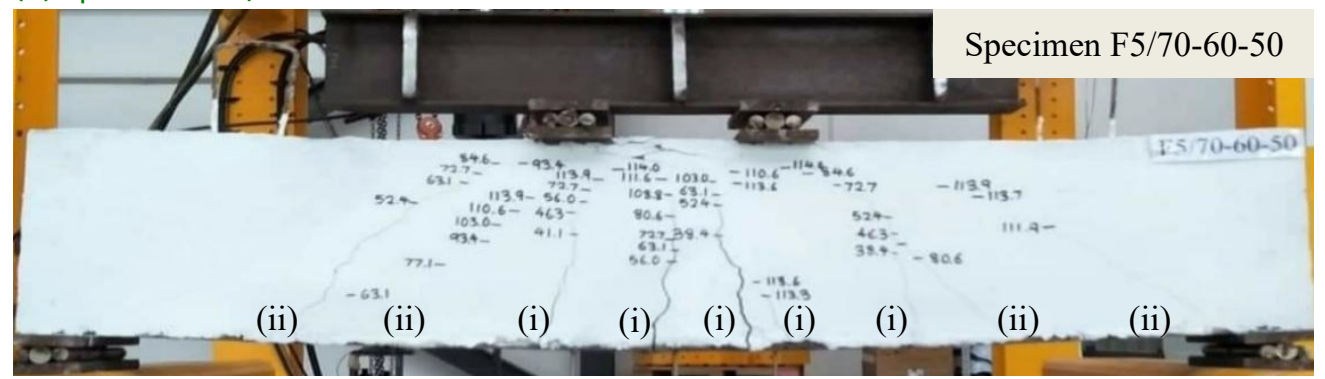

(f) Specimen F5/70-60-50

Figure 10. Crack Pattern of Specimens

Notes: (i) Flexural failure, (ii) Diagonal tension

Table 8. Failure Mode of Specimens

\begin{tabular}{|c|c|c|c|c|c|c|c|}
\hline \multirow[b]{2}{*}{ Specimens } & \multicolumn{3}{|c|}{ Number of Cracks } & \multicolumn{3}{|c|}{ Crack Width $^{* 1}$} & \multirow[b]{2}{*}{ Failure } \\
\hline & $\begin{array}{l}\text { Flexural } \\
\text { Failure }\end{array}$ & $\begin{array}{l}\text { Diagonal } \\
\text { Tension }\end{array}$ & $\begin{array}{l}\text { Shear } \\
\text { Compression }\end{array}$ & $W_{f}>W_{s}$ & $W_{f} \approx W_{s}$ & $W_{f}<W_{s}$ & \\
\hline $\mathrm{P} 1$ & 5 & 3 & - & $\sqrt{ }$ & $\mathrm{X}$ & $\mathrm{X}$ & Flexural \\
\hline $\mathrm{F} 1 / 50$ & 4 & 3 & - & $\sqrt{ }$ & $\mathrm{X}$ & $\mathrm{X}$ & Flexural \\
\hline $\mathrm{F} 2 / 60$ & 4 & 2 & - & $\sqrt{ }$ & $\mathrm{X}$ & $\mathrm{X}$ & Flexural \\
\hline F3/70 & 5 & 3 & - & $\sqrt{ }$ & $\mathrm{X}$ & $\mathrm{X}$ & Flexural \\
\hline $\mathrm{F} 4 / 50-60-70$ & 5 & 3 & - & $\sqrt{ }$ & $\mathrm{X}$ & $\mathrm{X}$ & Flexural \\
\hline $\mathrm{F} 5 / 70-60-50$ & 5 & 4 & - & $\sqrt{ }$ & $\mathrm{X}$ & $\mathrm{X}$ & Flexural \\
\hline
\end{tabular}

Note: ${ }^{* 1}$ Visual observation

\subsection{Effectiveness Assessment}

The effectiveness of the lightweight beams was evaluated based on the effective strength-toweight ratio ( $s w$ ) using Equation (1) as presented in Table 9. $W$ and $S$ represent the reduction of weight and strength with respect to the solid beam for specimen P1 respectively. The lightweight beam was considered effective when the effective strength-to-weight ratio $(s w)$ is greater than 1 (Lim and Ling, 2019). This means it has a higher reduction in weight than strength.

$s w=\frac{100-S}{100-W}$

where:

$W=\frac{W_{S}-W_{L}}{W_{S}} \times 100 \%$

$S=\frac{S_{S}-S_{L}}{S_{S}} \times 100 \%$

In Equations (2) and (3), $W_{S}$ and $W_{L}$ represents the weight of the solid and lightweight beam while $S_{S}$ and $S_{L}$ represent the strength respectively. Table 9 shows the effectiveness $(s w)$ of lightweight beams satisfy the required standard by being greater than 1. Therefore, it outperformed the solid beam based on the strength to weight ratio.

For industrial application, a significant percentage of concrete needs to be replaced. The requirement was set to be at least $10.1 \%$ replacement which was used as the mean value for all the specimens as presented in Table 9. Specimen F3/70 was discovered to have the highest amount of concrete replacement and effectiveness $(s w)$. It is, therefore, recommended to be used provided the creep as well as the damping and fire resistance meet the standard required by the industries. 
Table 9. Effective Strength to Weight Ratio of Specimens

\begin{tabular}{lllll}
\hline \multirow{2}{*}{ Specimens } & $\begin{array}{l}\text { Reduction of Weight, } \\
W(\%)\end{array}$ & $\begin{array}{l}\text { Reduction of Strength, } \\
S(\%)\end{array}$ & $\begin{array}{l}\text { Effective Strength to Weight } \\
\text { Ratio, }(\mathrm{sw})\end{array}$ & $\begin{array}{l}\text { Remarks } \\
(\mathrm{A} / \mathrm{NA})^{* 1}\end{array}$ \\
\hline Equation & $(2)$ & $(3)$ & $(1)$ & - \\
\hline P1 & - & - & 1.00 & - \\
F1/50 & 8.6 & 3.8 & 1.05 & $\mathrm{NA}$ \\
F2/60 & 10.1 & 1.3 & 1.10 & $\mathrm{~A}$ \\
F3/70 & 11.8 & 1.4 & 1.12 & $\mathrm{~A}$ \\
F4/50-60-70 & 10.1 & 2.4 & 1.09 & $\mathrm{~A}$ \\
F5/70-60-50 & 10.1 & 3.6 & 1.07 & $\mathrm{~A}$ \\
\hline
\end{tabular}

Mean

10.1

Notes: ${ }^{* 1} \mathrm{~A}=$ Adequate $(W \geqslant 10.1 \%$ and $s w \geqslant 1.0)$

$\mathrm{NA}=$ Non-adequate $(W<10.1 \%$ or $s w<1.0)$

\section{CONCLUSIONS}

This study aimed to determine the best shape of polystyrene to be used in a beam. The specimens were investigated based on the load capacity, deflection, ductility, crack pattern, and effective strength to weight ratio, and the following conclusions were drawn:

(a) The first crack load, yield strength, ultimate load, and effective strength to weight ratio increased as the corner radius increased from cylinder to ellipse.

(b) The occurrence of the first crack was delayed due to the placement of a smaller width of polystyrene at the bottom for F5/70-60-50 and this means it is possible to achieve a higher first crack load.

(c) The orientation of the polystyrene had limited contribution at the later stage.

(d) The ultimate deflection and ductility of lightweight beams were lower than the solid beam.

(e) The failure mode of lightweight beams was not affected by the cross-sectional shape of the polystyrene.

(f) The effective strength to weight ratio for all the lightweight beams was greater than 1.0 and this means they are effective. Less concrete was also required to achieve comparable strength with the solid beam.

It is possible to minimize the detrimental effects of the beam by using ellipse polystyrene due to its ability to perform better than the solid beam in the aspect of effective strength to weight ratio $(s w)$. There is, however, the need for further

studies to ensure the (a) creep, (b) damping resistance, and (c) fire resistance meet the industry's requirements. It is also recommended that the weight is reduced by at least $20 \%$ to ensure a meaningful reduction in the weight of the beam. These are, therefore, the possible new areas for future study.

\section{DISCLAIMER}

The authors declare no conflict of interest.

\section{AVAILABILITY OF DATA AND MATERIALS}

All data are available from the author.

\section{ACKNOWLEDGEMENT}

This work was supported by the Research Grants provided by the University College of Technology Sarawak, UCTS/RESEARCH/1/2018/09.

\section{SYMBOLS}

$a$

$d$

$d_{p}$

$E_{o .75 u}$

$f_{y}$

$l_{\text {eff }}$

$P$

$P_{i}$

$P_{u}$

$P_{y}$

SW
Distance between point load and support (mm)

Effective depth of beam (mm)

Diameter of polystyrene $(\mathrm{mm})$

Elasticity modulus before the yield state of the beam $(\mathrm{kN} / \mathrm{mm})$

Specified yield strength of

reinforcement bars $\left(\mathrm{N} / \mathrm{mm}^{2}\right)$

The effective length of the beam (mm)

Load capacity of the beam $(\mathrm{kN})$

First crack load of the beam $(\mathrm{kN})$

The ultimate load of the beam $(\mathrm{kN})$

Yield strength of beam $(\mathrm{kN})$

Effective strength to weight ratio 
$S \quad$ Reduction of strength (\%)

$S_{L} \quad$ Strength of the lightweight beam $(\mathrm{kN})$

$S_{S} \quad$ Strength of the solid beam $(\mathrm{kN})$

$W \quad$ Reduction of weight (\%)

$W_{f} \quad$ Width of the flexural crack $(\mathrm{mm})$

$W_{L} \quad$ Weight of lightweight beam $(\mathrm{kg})$

$W_{S} \quad$ Weight of solid beam $(\mathrm{kg})$

$W_{S} \quad$ Width of the shear crack (mm)

$x_{i} \quad$ Distance between two loading points (mm)

$\delta \quad$ Deflection of the beam (mm)

$\delta_{u} \quad$ Ultimate deflection of beam (mm)

$\delta_{y} \quad$ Yield deflection of beam ( $\mathrm{mm}$ )

$\Delta \quad$ Ductility of beam

\section{REFERENCES}

Ahmad, J.H.A. and Hadi, N.G.M., 2014. Structural Behavior of Reinforced Concrete Hollow Beams under Partial Uniformly Distributed Load. International Journal of Engineering, 20, pp. 130 145.

British Standard, 2009. Testing Hardened Concrete, BS EN 12390-3: 2009. United Kingdom: British Standards Institution.

British Standard, 2016. Metallic Materials Tensile Testing, BS EN ISO 6892-1: 2016. United Kingdom: British Standards Institution.

Chung, J.H., Park, J.H., Choi, H.K., Lee, S.C. and Choi, C.S., 2010. An Analytical Study on the Impact of Hollow Shapes in Bi-axial Hollow Slabs. Fracture Mechanics of Concrete and Concrete Structures, 30, pp. 1729 - 1736.

Hai, L.V., Hung, V. D., Thi, T. M., Thoi, T.N. and Phuoc, N.T., 2013. The Experimental Analysis of Bubble Deck Slab using Modified Elliptical Balls. In: Proceedings of the Thirteenth East Asia-Pacific Conference on Structural Engineering and Construction (EASEC-13), Japan, pp. 1 - 9.

Jesudhason, W.G. and Hemalatha, G., 2014. Experimental Investigation on Beams Partial Replacement below the Neutral Axis. In: National Conference on Technological Innovations in Structural Engineering, pp. 567 - 898.
Kum, Y.J., 2011. Cracking Mode and Shear Strength of Lightweight Concrete Beams. PhD Thesis. National University of Singapore.

Manikandan, S., Dharnar, S. and Robertravi, S., 2015. Experimental Study on Flexural Behaviour of Reinforced Concrete Hollow Core Sandwich Beams. International Journal of Advance Research in Science and Engineering, 4, pp. 937 - 946.

Mathew, I. and Varghese, S.M., 2016. Experimental Study on Partial Replacement of Concrete In and Below Neutral Axis of Beam. International Journal of Innovative Research In Technology, 3, pp.188-192.

Moayyad, M.A. and Naiem, M.A., 2013. Shear Reinforcements in the Reinforced Concrete Beams. American Journal of Engineering Research (AJER), 2, pp. 191 - 199.

Mohamad, S.Y. and Ramli, A., 2012. Reinforced Concrete Design to Eurocode 2. Malaysia: University Teknologi Malaysia.

Nor, F.Z. and Roslli, N.M., 2014. The Effects of Inclined Shear Reinforcement in Reinforced Concrete Beam, pp. 138 - 149.

Lim, Y.T. and Ling, J.H., 2019. Incorporating Lightweight Materials in Reinforced Concrete Beams and Slabs - A Review. Borneo Journal of Sciences and Technology, 1, pp. $16-26$.

Shaaban, I.G., Shaheen, Y.B., Elsayed, E.L., Kamal, O.A. and Adesina, P.A., 2018. Flexural Behaviour and Theoretical Prediction of Lightweight Ferrocement Composite Beams. Case Studies in Construction Materials, 9, pp. 204.

Thaar, S.S A., 2015. Reinforced Concrete Moderate Deep Beams with Embedded PVC Pipes. Wasit Journal of Engineering Science, 3, pp.19-29.

Zainorizuan, M.J., Koh, H.B., Shahrul, N.M., Ismail, M., Hissyam, H. and Nurul, H.H., 2016. Structural Behavior of Short-Span Reinforced Concrete Beams with Foamed Concrete Infill. ARPN Journal of Engineering and Applied Sciences, 11, pp. 9820 - 9825. 
[This page is intentionally left blank] 